\title{
Revisiting Brussels Tapestry, I700-I740: New Data on Tapissiers Albert Auwercx and Judocus de Vos

\author{
Koenraad Brosens
}

Based on new archival findings, this essay maps the life and business strategies of Brussels tapissiers Albert Auwercx and Judocus de Vos. It shows that categorising Auwerxc as a minor tapissier - a label he was assigned in the past - ignores the underlying structure and dynamics of the industry. Brussels tapissiers created an intricate web of social networks that generated trust, which paved the way for semi-structured and flexible cooperation between small firms. Judocus de Vos also belonged to the Brussels social and production networks but made his name as a commercial link and broker between Brussels, the Antwerp-Oudenarde production and trading complex, and the European élite - particularly after I7I9 when he handed over the reins and assets of the De Vos workshop to his brother Jan-Frans.

\section{INTRODUCTION}

Brussels tapestry dating from the first half of the eighteenth century has been paid significant attention in recent times. A number of articles focused on sets co-designed by Jan van Orley (I665-I735) and the landscape painter Augustin Coppens (I668-I740) ${ }^{\mathrm{I}}$ and on those painted by Van Orley's successor Philippe de Hondt (I683-I74I). ${ }^{2}$ These were by far the most prolific Brussels tapestry designers of the period. Other studies focused on the production and business activities of tapissiers (tapestry producers) Jean-Baptiste Vermillion (I68I-in or before I748), 3 Urbanus Leyniers (I674-I747), who directed a dye works as well as a tapestry workshop ${ }^{4}$ and the ubiquitous Judocus de Vos (I66I-I734) who, according to the studies, was in charge of the largest workshop, with its twelve looms. De Vos also subcontracted to other tapissiers, traded tapestries in Antwerp and Oudenarde and, as the one commissioning eleven or twelve sets of cartoons, heavily influenced, if not defined, artistic developments in tapestry design in around $1700 .^{5}$

These studies clearly show that Brussels tapestry in the first half of the eighteenth century can be divided into three phases. The first phase, I700 to I7IO, coincides with the period in which Judocus de Vos commissioned sets from Van Orley and Coppens, such as The Triumph of the Gods I and The Story of Telemachus I, and thus initiated the neo-Baroque style. Together with the genre Teniers, dating from the closing decades of the seventeenth century, this new, sophisticated manner, full of encyclopaedic references to Flemish, French and Italian art of the sixteenth and seventeenth centuries, would 
Revisiting Brussels Tapestry, I700-I740

secure the position of Brussels in the European tapestry markets in the first half of the eighteenth century.

In the second phase, I7II to I725, Urbanus Leyniers continued to promote neoBaroque tapestry design and the genre Teniers. His investment in new cartoons by Van Orley and Coppens should be seen against the background of the Brinck affair. This affair started in I7II, when nearly all Brussels tapissiers, led by Judocus de Vos, supported Leyniers's employee Jan Brinck (I674-I743) in his attempts to open a new dye works in Brussels. ${ }^{6}$ Leyniers went to great lengths to prevent this from happening because he risked being swept away by Brinck, who had been in Leyniers's employment since I702. During this time he had learned all there was to know about the secret dyeing recipes used and perfected by members of the Leyniers family down the years. Despite Leyniers's opposition, Brinck was eventually allowed to open his dye works. Leyniers, however, immediately rose to defend his own position. He started trading in Antwerp, Brussels and Oudenarde sets, established a large-scale tapestry workshop and commissioned a wide range of cartoons from Van Orley and Coppens, including The Triumph of the Gods II and The Story of Telemachus II.

The third and last phase, I725 to I750, witnessed the reaction of Jasper van der Borcht (I675-I742) and Peter van den Hecke (c. I675-I752) to the growing power of Urbanus Leyniers. They promoted Philippe de Hondt's gồt moderne, a new style that favoured the stylised and idealised Utopia of modern-day and everyday events over the essentially epic and highbrow neo-Baroque approach.

Although this scenario rests firmly on archival sources and preserved tapestries, it is not only incomplete but also flawed. Firstly, the genealogy and biographies of these tapissiers, including those of Judocus de Vos, are surprisingly wanting. Secondly, several entrepreneurs were never given sufficient attention. Albert Auwercx and the Auwercx workshop are good examples of this. Alphonse Wauters sealed their fate in art history as far back as I 878 in his pioneering study of Brussels tapestry. In it, he portrays Auwercx as a secondary actor using his small workshop of only five looms to do mainly subcontracted work. ${ }^{7}$ As a consequence of this, Albert Auwercx and his son and successor, Philippe, lost any appeal they may have had to subsequent researchers. Thirdly, closer inspection shows that, in some instances, accepted wisdom rests upon methodological quicksand. For example, the claim that Judocus de Vos owned eleven or twelve sets of cartoons, and as such should be viewed as a leading light, rests solely upon the assumption that, because he was the manager of the largest workshop, he would necessarily have the greatest appetite for new cartoons. Apart from anything else, there are no archival documents that describe De Vos as the unequivocal owner of the cartoons.

This essay aims to increase our understanding of the Brussels production landscape between about I700 and I740 by focusing on the lives and the business activities of Albert Auwercx and Judocus de Vos. The backbone of this paper comprises a substantial amount of new data extracted from Brussels parish records and Antwerp and Brussels legal archives. Three unpublished documents are central to this: an inventory of the Auwercx estate compiled in I7I8; a contract entered into in I7O2 by Judocus de Vos and the Antwerp tapestry entrepreneur Nicolaas Naulaerts (d. I703); and a Memoire des differents tentures de tapisseries compiled by Judocus de Vos in I727 
(Appendices I-3: http://dx.doi.org/IO.II79/00404969I2Z.000000000IO.SI; http://dx.doi. org/IO.I I79/00404969I2Z.000000000I0.S2; http://dx.doi.org/IO.I I79/00404969I2Z.0000 $\left.00000 \mathrm{IO}^{\circ} \mathrm{S}_{3}\right) .{ }^{8}$

\section{Albert Auwercx \& Co.}

What little information we have about Albert Auwercx was published in 1878 by Wauters. ${ }^{9}$ Auwercx, who opened his workshop in 1657, was granted exemption from taxation by the city administration in $167 \mathrm{I}$, which means that, at the time, his share of the industry must have been substantial. However, Auwercx frequently acted as a subcontractor for other tapissiers; in the early years of the eighteenth century he only had five looms (I705) and received financial support from the Brussels commerciecaemer (Chamber of Commerce) (I703-I705). These factors would indicate that he played a rather insignificant role in the Brussels industry. Subsequent literature paid scant attention to Auwercx, which only reinforced this impression. ${ }^{\text {Io }}$

However, a newly discovered inventory of Auwercx's estate, compiled on 3 December I7I8, depicts Auwercx as an influential entrepreneur who had at his disposal several highly fashionable sets of cartoons (Appendix I: http:/dx.doi.org/IO.II79/ 00404969I2Z.000000000IO.SI). The inventory was compiled at the behest of nine of Auwercx's children who had outlived their parents, that is, Carolus-Franciscus, Daniel, Gaspar, Johannes, Magdalena, Maria, Nicolaas, Philippe and Willem Auwercx. The document comprises two parts. The first section surveys the division of the Auwercx estate as recorded by his descendants on 9 May I7I4. The second section lists all items that his children sold between 9 May I7I4 and 3 December I7I8.

In I7I4, all nine children received a share of fl.I,822-5 each. Johannes, Nicolaas and Willem received this amount in cash. The share of Carolus-Franciscus, a clergyman, consisted of a house in the Schietspoelstraat that he had been given by his father when he had been ordained as a priest in 1699 (fl.I,000), a share in a house in the Hoogstraat (fl.527) and fl.295-5 in cash. Philippe, Daniel, Gaspar, Magdalena and Maria formed a partnership that inherited the house and workshop of their late father in the Huidevettersstraat. The house was valued at fl.3,300; the furnishings at fl.870-7. The workshop's moveable goods were valued at fl.2,949. These goods included not only looms, shuttles and silks, but also two sets of cartoons painted in oil on canvas: the eight-piece Pleasure of the Gods (i.e., The Triumph of the Gods I) and the six-piece Story of Telemachus I. The document shows that both sets were created by Van Orley and Coppens. ${ }^{\text {II }}$ In addition, the partners received fl.I,99I-9 in cash. In total, the five partners inherited about fl.9, II , the equivalent of fl. I,822-5 per person.

The estate of Albert Auwercx, however, was worth more than nine times fl.I,822-5, or fl.16,400 in total, since a substantial part of the estate remained undivided in I7I4. Among the goods that remained undivided were six tapestries depicting the History of the Moncada Family, which were valued at $\mathrm{fl} \cdot 3, \mathrm{I} 27^{\mathrm{I2}}$ and the cartoons of five sets: a series of six cartoons painted in oil on canvas showing the Story of Rinaldo and Armida by Victor Janssens (I658-I736) and Augustin Coppens; a set of six cartoons painted in oil on canvas depicting Teniers by Van Orley and Coppens; a set of eight cartoons painted in tempera on paper showing Landscapes by 'seigneur Coppens' (either Augustin or his father François (І628-І685)); a set of eight cartoons painted in tempera on paper 
Revisiting Brussels Tapestry, I700-I740

depicting the Story of Saint Paul; and five cartoons painted in tempera on paper showing the Story of Moses. The document does not cite the designers of these last two sets but reveals that Hendrik II Reydams (I650-I7I9) owned the remaining five cartoons of the Moses series and that Philippe Auwercx had a share of one third in the Saint Paul cartoons. As the cartoons of both sets were painted in tempera on paper, they can be identified with series that were created in the sixteenth century and were updated and recycled throughout the seventeenth century. ${ }^{\mathrm{I}}{ }^{3}$ The value of the five sets of cartoons was not recorded in I7I4, but they were sold for fl.I,I99 in I7I8. This means that in I7I4 Auwercx's property was worth fl.20,726 in total.

The I7I8 document contradicts the traditional image that we have of Albert Auwercx as a somewhat pedestrian entrepreneur. It proves not only that Auwercx was a wealthy man, ${ }^{14}$ but also that he was the first to invest in the neo-Baroque style when he, between 1700 and his death in 1709 , commissioned the cartoons of Rinaldo and Armida, Telemachus I and The Triumph of the Gods I. Since Auwercx also owned a set of Teniers cartoons by Van Orley and Coppens, his catalogue was state-of-the-art. In short, Auwercx was instrumental in launching Brussels tapestry into the eighteenth century. New biographical data confirms his influential role.

Albert Auwercx was christened on Io February I629 in the Brussels Church of Our Lady of the Chapel, ${ }^{15}$ the parish that for many years was the hub of the tapestry industry. His father was Marcus; his mother was Clara Canart. ${ }^{16}$ While neither of his parents can be linked to tapestry, Albert Auwercx certainly moved in tapissiers circles. On 8 May 1654, Auwercx married Clara van den Bossche (d. I698). ${ }^{\text {I7 }}$ She was related to Johanna van den Bossche (d. I652), wife of tapissier Peter de Pannemaker (b. I597), ${ }^{18}$ a descendant of the famous tapestry producers Peter (c. I475-in or before I539) and Willem de Pannemaker (c. I5 I5-in or after I567). ${ }^{\text {I9 }}$ Auwercx's best man at the wedding was tapissier Jan Bransoen. According to his application for tax relief, Auwercx opened his workshop about three years after he got married. ${ }^{20}$

Auwercx and Van den Bossche had eleven children, all of whom were christened in the church of Our Lady of the Chapel between I655 and I676. There were nine sons: Nicolaas (I655-C.I740), ${ }^{21}$ Albertus-Franciscus (I656-I669), ${ }^{22}$ Philippe (I663-I740), ${ }^{23}$ Johannes (I664-I737), ${ }^{24}$ Michael (I666-I678), ${ }^{25}$ Daniel (I667-I723), ${ }^{26}$ Willem (I67II755), ${ }^{27}$ Carolus-Franciscus (I672-after I7I8), ${ }^{28}$ and Gaspar (I676-I755). ${ }^{29}$ The two daughters were Magdalena (I659-I720) ${ }^{30}$ and Maria (I660-I733). . $^{\text {I }}$ Albert Auwercx lived to be eighty and was buried in the church of Our Lady of the Chapel on 3I August I709. ${ }^{32}$

Interestingly, at least six of the nine children born after Auwercx opened his workshop in I657 had godparents who can be linked to the tapestry industry. Jan Bransoen became godfather to Albert's daughter Maria. ${ }^{33}$ Philippe Auwercx's godfather was Philippe van der Bruggen, who was related to the Van der Bruggen family of tapissiers. ${ }^{34}$ Philippe Auwercx's godmother was Barbara Peeterens, the wife of workshop manager Willem van Leefdael (I632-I688). Johannes Auwercx's godfather was Willem van Leefdael's father Jan (I603-I668). ${ }^{35}$ Tapestry producer Daniel II Eggermans (I604-I669), whose mother Maria van den Bossche was presumably related to Albert Auwercx's wife Clara van den Bossche, ${ }^{36}$ was godfather to Daniel Auwercx. ${ }^{37}$ Willem Auwercx's godfather was Willem van Leefdael..$^{3}$ Finally, Gaspar's godfather was Gaspar Leyniers, who ran the leading dye works in Brussels and belonged to an important family of tapestry entrepreneurs and dye works directors. ${ }^{39}$ 
In this way, through marriage and what could be called astute christening politics, Albert Auwercx, a newcomer to the industry, embedded himself slowly but surely in a web of social and business networks populated by high-profile tapissiers. By I676, Auwercx's list of friends reads like a who's who of the Brussels tapestry élite. Auwercx further enhanced his position within this network by shouldering responsibility for the administration of a sieckbusse (sick pay) that connected various tapissiers including Willem van Leefdael, Jan Bransoen, Gillis Ydens and Jan van Rottom..$^{\circ}$ Documents also reveal that Auwercx served several terms as dean of the tapestry guild after $1679 .{ }^{4}$

Unsurprisingly, Auwercx's networking activities spilled over into business ventures, as evidenced by the following examples. Auwercx collaborated with Willem van Leefdael, Erasmus II or III de Pannemaker, Gillis Ydens and Jan van Rottom on an edition of the Story of Diana in I668..$^{2}$ Auwercx and Ydens further co-produced at least one edition of the Story of Cyrus after recycled sixteenth-century cartoons that were also used in the De Pannemaker workshop. ${ }^{43}$ In 1678, the Story of Saint Paul cartoons, which were itemised in the I7I 8 document, were used by Albert Auwercx, Willem van Leefdael and Jan II Leyniers (I630-I686), whose son Jan (b. I675) was a godchild of Willem van Leefdael.44 In I688 and I69I Auwercx worked as a subcontractor for Gaspar Leyniers, godfather to his son Gaspar. ${ }^{45}$

Auwercx was not the first tapissier to develop and reap the rewards of a calculated networking strategy. While our insight into the networks of most Brussels tapissiers may be fragmented, earlier studies have shown that, throughout the seventeenth century, tapestry entrepreneurs were as proficient in weaving networks as they were in weaving tapestries and it is reasonable to assume that targeted research in archival collections, like the parish registers, will produce a wealth of data that supports this image. ${ }^{46}$ It is, therefore, safe to say that Brussels tapestry production of the seventeenth and early eighteenth century was firmly rooted in social networks. ${ }^{47}$ These interpersonal relationships fostered trust, and trust improved economic performance — it was, in fact, the lifeblood of the industry. It is a truism that tapissiers faced ongoing demand for capital alongside uncertainty and risks. Tapestry production was exceptionally time-consuming, making the cost of labour substantial, and the material used to produce tapestries raised the cost further. Moreover, investment in new cartoons and editions, required by commissioned work as well as work done on spec, was heavy and hazardous because market information was often lacking or unreliable. While producers tried to understand, satisfy and create consumer demand, the recovery of their investments was usually slow, at times problematic and occasionally completely absent when clients and patrons defaulted or died before the commission was complete. Trust in its various manifestations, such as mutual aid, cooperation and information exchange, obviously distributed and minimised uncertainty and risk..$^{8}$

The fact that Auwercx and his colleagues enjoyed a relationship rooted in trust explains the apparent discrepancy between the limited size of his workshop, on the one hand, and his economic power on the other. Guild regulations presented tapissiers with the opportunity to establish large-scale workshops as there were no quotas on either looms or output. ${ }^{49}$ But within the moral community formed by Brussels tapissiers, the most obvious advantage of a large-scale firm, that is, consistent supervision of labour productivity and quality, was irrelevant. ${ }^{\circ} \mathrm{A}$ production sector that comprised a constellation of small, flexible firms that could respond to opportunities and challenges, 
Revisiting Brussels Tapestry, I700-I740

nourished by high levels of trust and solidarity, that could join forces to become larger and more stable production units, where information and resources were pooled, was the best business model for spreading uncertainty and risk. Consequently, the number of looms that a tapissier had was no indication of his position within the tapestry industry, or of his position on the socio-economic ladder for that matter. Instead, tapissiers derived their power and resilience from their relationships with other players, and as such from their position within their interwoven network of social and business contacts.

Albert Auwercx grasped this principle and exploited it to the full, and on his death he passed on to his sons, particularly Philippe who assumed his father's role as head of the Auwercx workshop, an enterprise that had unlimited potential for further development. However, the probate inventory recorded after Philippe Auwercx's death in I740 showed that he had been marking time. ${ }^{51} \mathrm{He}$ had not acquired any new cartoon sets between I7IO and I740 - on the contrary, the cartoons of the Teniers set by Van Orley and Coppens had disappeared from his catalogue and he had only six sets (together amounting to thirty-three tapestries) in stock..$^{22}$ When Urbanus Leyniers died in I747, he had twenty-four Brussels sets (I2I tapestries) in stock, alongside nine Antwerp sets (thirty-nine tapestries), fifty-one Oudenaarde sets (I87 tapestries) and the cartoons of seventeen sets. ${ }^{53}$ An explanation for this stagnation, bordering on regression, that the Auwercx workshop went through could be found in the Brinck affair (I7II) that tore through the industry's social fabric. While Albert Auwercx was able to establish a name for himself in an entrepreneurial and social community in which conflicts were minor and short-lived, Philippe Auwercx had to choose sides in an affair that completely disrupted that same community that had served his father's purposes so well. In hindsight, it is clear that he made the wrong choice in supporting Brinck. It was after the latter had opened his dye works that Urbanus Leyniers commissioned cartoons depicting The Triumph of the Gods II and The Story of Telemachus II from Van Orley and Coppens, sets that were virtually identical to Auwercx's sets of similar titles that together constituted the cream of his catalogue. The nineteen documented editions from his Triumph and Telemachus sets that Leyniers sold between I7I7 and I $734^{54}$ were missed opportunities for Auwercx. Equally, the various Teniers sets that Leyniers had in his catalogue, and of which he sold no less than twenty-seven editions between I7I 2 and $\mathrm{I} 734,55$ were also an obstacle on the path to growth for the Auwercx workshop.

The rehabilitation of Albert Auwercx and the fact that the explosive growth of Leyniers' workshop clearly inhibited the growth of Auwercx's workshop force us to reconsider Judocus de Vos's position within the industry. Archival research has brought new genealogical and biographical data to light, data that shows us a sharper image of De Vos's business activities.

Judocus de Vos \& Co.

Earlier studies have revealed that Judocus de Vos was the son of Marcus de Vos, a workshop manager to whom the City Council granted tax relief in I663 and who was dean of the tapestry corporation several times in the $16705 .{ }^{56}$ Apparently Marcus had a brother, Govard, who was also dean of the tapestry corporation a number of times in the late I670s and early I680s. Since there are no known tapestries with Govard's 
signature on them, it must be assumed that he only worked as a subcontractor or employee. The Brussels parish records reveal that Govard de Vos died in I7II. ${ }^{57}$ They also show that Marcus de Vos was christened in the church of Our Lady of the Chapel in $1630^{58}$ and that he had at least one other brother, Jacob (b. I629), who had no links to the industry. ${ }^{59}$

Marcus de Vos died in $1704^{60}$ which means that he was a close contemporary (I63OI704) of Albert Auwercx (I629-I709). Just like Auwercx, Marcus de Vos lived in the parish of Our Lady of the Chapel, and it comes therefore as no surprise that that he can be linked to the interwoven networks of this parish. For instance, Marcus de Vos was godfather to Marcus de Pannemaker (b. I664), son of Eramus III (b. I627). Yet it is clear that De Vos's attempts to become entrenched in this social scene were less obvious than those of Auwercx. So far, his wife, Johanna-Antonia Berewijns, cannot be linked to the Brussels industry, and none of their four children, who were christened in the Church of Our Lady of the Chapel, had godparents who belonged to the tapissiers' network: Judocus (I66I-I734), ${ }^{61}$ Jan-Frans (I664-I750), ${ }^{62}$ Christiaan (I666-I723) ${ }^{63}$ and MarcusJohannes (b. 1676). ${ }^{64}$ The latter has not been mentioned in previous studies. The date that Christiaan died ( $\mathrm{I}_{723}$ ) is also new information, as are his profession and place of residence, as recorded in the death register (tapissier op de hooghplaetse) ${ }^{65}$

It is not obvious from the Brussels parish records when Jacob de Vos was christened. He was a 'surgeon' who can be identified on the basis of a notarial deed as the brother of Judocus de $\operatorname{Vos}^{66}$ and his date of death, I73I, is known. ${ }^{67}$ One Hendrik de Vos, registered in 1677 in the Brussels corporation of painters as 'son of Marcus', has in the past been identified as the elder brother of Judocus de Vos, but in all probability he should be scrapped from the family tree since he is more likely to be the son of sculptor Marcus de Vos, whose father was also called Hendrik and who was given freedom of the city of Brussels in 1674 and the freedom of the civic guard (burgerwacht) in $1687 .{ }^{68}$

While the date of Judocus de Vos's marriage to Johanna-Maria Verheylewegen, 9 September I685, was already known, new research has revealed that De Vos and Verheylewegen got married in the Church of Our Lady of the Chapel. ${ }^{69}$ From De Vos's will ${ }^{\circ}$ and two notarial deeds, ${ }^{7 \mathrm{I}}$ it appears that the couple had at least six children: Johanna-Antonia, Jacob (d. I74I), who had psychological problems, ${ }^{72}$ Catharina, Jan-Frans (d. I759), Johanna-Catharina and Anna. The names of these children were recorded in various documents in this specific order, which may indicate that they were mentioned in descending order of age. Remarkably, new research shows that none of the children were christened in the Church of Our Lady of the Chapel, which is a clear indication that Judocus de Vos did not stay in the parish after his marriage, the parish where he had grown up. It is still not clear where Judocus de Vos and Johanna-Maria Verheylewegen settled after they were wed. There is a good chance that the pair moved more than once: archival research has shown that Jan-Frans de Vos was christened in the Church of Sint Goriks in $1697^{73}$ and that the couple lived in the parish at the time, but the rest of Judocus's children were not christened in the same church. ${ }^{74}$ Since it is not yet known where the children were christened, it is not possible to establish whether Judocus de Vos recruited godparents from among the Brussels tapissiers.

The growth of the De Vos family during the period I685 to I700 went hand in hand with the advance of Judocus de Vos's professional career. He registered in $\mathrm{I}_{684}$ as a clijncremer with the guild of merchants, which allowed him to trade in luxury and 
Revisiting Brussels Tapestry, I700-I740

'semi-luxury' goods. ${ }^{75}$ It transpires that Judocus de Vos was soon well off, so much so that he was able to act as financial guarantor for his father in I686, I687 and I688. During this time (I68I-I696) his father was engaged by Antwerp tapestry entrepreneurs Nicolaas Naulaerts (d. I703) and Jan van Verren (d. I7II) to produce tapestry sets. ${ }^{76}$ Similar collaborations between businessmen from Brussels and Antwerp had characterised the sector since the late sixteenth century and throughout the seventeenth century they were formed and nurtured in the tapissierspanden of Antwerp and Brussels. These hives of activity were not only marketplaces frequented by Flemish tapestry merchants and European traders and intermediaries, but also information centres where Flemish producers and dealers built up mutual trust and formed incidental and, on occasion, structural alliances. ${ }^{77}$

During the second half of the I680s, Judocus de Vos was registered in the Brussels tapestry corporation. The registers have unfortunately not survived, so the exact year cannot be established, but given that he was armbusmeester of the corporation in $1692,{ }^{78}$ Judocus de Vos must have joined the corporation at the latest in I69I. The oldest known document in which Judocus de Vos is mentioned specifically as a Brussels tapissier dates from I698: this is when he signed himself up, together with tapissiers Jacob van der Borcht (d. in or before I7I3) and Jan Cobus (d. I698-I700), to produce a three-part series depicting the Victories of William III of England.79 While this series was in production, ${ }^{8 \circ}$ Judocus de Vos was project manager of another highly prestigious commission - the largest series of Brussels tapestries in the world, that is, the twenty-nine tapestries of the New Testament that were woven between I699 and I700 for the Grand Master of the Knights of Malta for St John's Cathedral in Valletta. ${ }^{8 \mathrm{I}}$ Alongside these unique high-profile commissions, De Vos produced several commercially successful series, including Ovid's Metamorphoses and Il Pastor Fido, ${ }^{82}$ and he had close contact with Nicolaas Naulaerts between I700 and I70I. ${ }^{83}$ The traffic in tapestries between these two men went both ways: De Vos supplied Naulaerts with Brussels tapestries and Naulaerts reciprocated with Antwerp and Oudenarde tapestries.

A newly discovered contract reveals that Naulaerts and Judocus de Vos decided to consolidate their dealings on 3I July I702 by establishing a business alliance (Appendix 2: http://dx.doi.org/IO.II79/00404969I2Z.000000000IO.S2). ${ }^{84}$ The contract itemises all editions that the businessmen had in stock that were joint assets. It also listed the cartoon sets that were owned by Naulaerts and De Vos. These were not joint assets, but all future editions based on these cartoons would be co-productions. This information about the sets and cartoons belonging to Naulaerts should be linked to the data in the Memoriael Naulaerts, a compendium of the Naulaerts' company records dating from I699 to I709, which was published in $1936 .{ }^{85}$ A detailed analysis of these facts and figures will be the subject of a separate study; in this contribution, the attention focuses on what the document reveals about the nature and scope of De Vos's activities and strategies - and what the document reveals is surprising.

Only five cartoon sets were listed in the contract, that is, Il Pastor Fido, Teniers, The Holy Church, the Pleasures of the Princes and a set of cartoons by the landscape painter Lucas Achtschellinck (I626-I699). The limited number of sets is unexpected, as is the composition of the catalogue. It will come as no surprise that De Vos, in line with most Flemish tapestry entrepreneurs, had a set of Teniers cartoons in around $1700^{86}$ and that he also had the set of cartoons depicting The Holy Church, that is, The New Testament 
series commissioned by the Grand Master of the Knights of Malta in around I699. This is to be expected since De Vos produced several — albeit modest — re-editions of this set. ${ }^{87}$ But the Pastor Fido cartoons by Lodewijk van Schoor (d. I702) and Pieter Spierinckx (I635-I7II) have in the past been assigned as property of the associated Brussels tapissiers Hieronymus le Clerc and Jasper van der Borcht. ${ }^{88}$ That De Vos owned a set of cartoons depicting Landscapes by Achtschellinck is equally surprising given that no known Landscape tapestries can be attributed to De Vos. Equally surprising is the set depicting the Pleasures of the Princes. To this day, tapestry scholars have never mentioned this series; no tapestries have surfaced that point to the existence of these series, which in itself suggests that it was not very successful. ${ }^{89}$

The composition of De Vos's catalogue of cartoons is not the only surprising aspect: his stock of twelve woven sets is also remarkably small given that his business partner Naulaerts listed no less than forty-seven sets. Four of De Vos's sets were cheap Oudenaardse products. One set depicting Ovid's Metamorphoses was made by Jacob van der Borcht. The stock included one set of the Pleasures of the Princes and two sets of Il Pastor Fido, all of which were woven in Brussels. While the tapissier involved was not mentioned by name, it is safe to assume that De Vos himself produced them. The three remaining sets recorded in the 1702 contract, depicting Teniers, The Story of Perseus and The Four Continents and Related Allegories, were in Nicolas Lang's warehouse in Frankfurt. ${ }^{\circ}$ These sets were also produced in Brussels. Once again, the producer's name is not mentioned, so presumably De Vos also produced them. He had a set of Teniers cartoons, and surviving tapestries and documents clearly indicate that he executed editions of the Story of Perseus and The Four Continents and Related Allegories. These were based on cartoons by Lodewijk van Schoor, belonging to Jan van Verren and Nicolaas Naulaerts respectively. ${ }^{\text {I }}$

The I702 contract reveals that De Vos developed an entrepreneurial strategy that was different to the one followed by Albert Auwercx. While Auwercx focused on extending his production, De Vos tried to position himself as an entrepreneur-cum-gatekeeper between the Brussels production networks and the Antwerp-Oudenarde production and trading networks.

His decision to formalise the old relationship with Naulaerts may have been triggered by two initiatives that Urbanus Leyniers demonstrated a couple of weeks earlier: in June 1702 , he hired Jan Brinck as supervisor of the Leyniers dye works ${ }^{92}$ and, almost immediately after this, he registered as a master with the Brussels tapestry corporation. ${ }^{93}$ This gave him the time and opportunity to become involved in the market as a tapestry entrepreneur. Consequently, it is plausible that Judocus de Vos decided to focus on the 'company for trading in tapestries' as a buffer against Leyniers's plans.

Naulaerts died in I703, and in October I704 the Naulaerts-De Vos alliance was formally dissolved by Naulaerts' successors, that is, his son Jan-Jozef and François Blommaert. ${ }^{94}$ This in itself does not mean that Judocus de Vos no longer had commercial dealings with these entrepreneurs. ${ }^{95}$ In 1705 , after the death of his father, Judocus de Vos was granted exemption from taxation by the city administration. ${ }^{96}$ In that same year, there were twelve looms in his workshop. Presumably De Vos remained at the helm until I7I9. During that period he was instrumental in the Brinck affair, he continued to trade in Antwerp and Oudenarde tapestries and he completed several prestigious commissions, including the re-edition of the Conquest of Tunis series for the Emperor 
Revisiting Brussels Tapestry, I700-I740

Charles VI and the Victories for the Duke of Marlborough. In I7I5 he became estate agent for the Duke of Arenberg and he moved to a large property in the Nieuwstraat in one of Brussels' fashionable districts. ${ }^{97}$

In a letter written in I7I9, however, de Vos stated that he planned to bring an end to his activities as a tapissier. ${ }^{98}$ It is probably no coincidence that it was in I7I9 that Judocus's brother, Jan-Frans de Vos, was granted exemption from taxation by the city administration. ${ }^{99}$ In his application, Jan-Frans stressed that he had worked in the De Vos workshop since the death of their father Marcus and that he had taken over as head of the business, which no doubt means that Judocus de Vos had stepped aside. A newly discovered probate inventory surveying all 'furniture or assets found in the home of Mister Judocus de Vos', compiled about a month after the death of De Vos's wife Johanna-Maria Verheylewegen in I726, confirms this assumption. Presumably by then all assets of the workshop had been transferred to Jan-Frans de Vos, for the document reveals that Judocus de Vos did not own sets of cartoons, series or looms. ${ }^{100}$ The distribution of Judocus de Vos's estate paints the same picture: De Vos had neither cartoons, tapestry sets nor looms. ${ }^{\text {го }}$ While we can only speculate as to why Judocus de Vos handed over the workshop to his brother, his advanced age and the supremacy of the Leyniers workshop will in all probability have played a role in his decision.

Whatever the case may be, this does not mean that Judocus de Vos withdrew from the trade after I7I9 - on the contrary. An unpublished Memoire from I727 shows that he became a marchand en chambre, brokering between his brother's workshop and its European clientele. In I727, Charles Hope, first Earl of Hopetoun (I68I-I742), contemplated buying one, or possibly more, Brussels tapestry sets for Hopetoun House ${ }^{\mathrm{I} 22}$ and contacted Judocus de Vos. ${ }^{103}$ The latter recorded a Memoire des differents tentures de tapisseries, surveying tapestry sets that he was in a position to supply (Appendix 3: http://dx.doi.org/IO.II79/00404969I2Z.000000000I0.S3). ${ }^{104}$ The document lists eight upholstered chairs with grotesque decoration, five petit point embroideries showing grotesque motifs 'à la mode de la Chinoise', and eleven editions of various sets. Judocus de Vos always included the dimensions of the tapestries and the prices per ell. He never mentioned the name of the designer, but the basic yet succinct titles and descriptions of the tapestries make it possible to identify the sets.

Four of the eleven editions were woven after seventeenth-century cartoons: an eightpiece Story of Titus and Vespasian series, after designs by Charles Poerson (I609-I667), ${ }^{\text {105 }}$ a six-piece set showing The Months which, according to De Vos, could be combined with a set of four small tapestries depicting The Four Continents, after designs by David III Teniers (1638-1685) ${ }^{\text {106 }}$ and a five-piece set of The Four Continents and Related Allegories created by Lodewijk van Schoor in the last quarter of the seventeenth century. ${ }^{107}$ Apart from these, De Vos listed three sets of Teniers, a six-piece set of The Triumph of the Gods I, a seven-piece set of The Story of Telemachus I, ${ }^{\mathrm{r} 08}$ a six-piece set depicting Plutarch's Illustrious Men after designs by Victor Janssens and Coppens ${ }^{109}$ and, finally, a nine-piece set of The Art of War II designed by Philippe de Hondt. ${ }^{\text {Io }}$

Not all sets were woven in the De Vos workshop. The seventeenth-century sets depicting Titus and Vespasian, The Months and The Four Continents can in all probability be linked to the sets that were auctioned in Brussels in I7II following the bankruptcy of Gerard Peemans $(\mathrm{I} 637 / 39-1725)^{\mathrm{III}}$ and the set of Plutarch's Illustrious Men must have been produced by Judocus de Vos's nemesis Urbanus Leyniers. ${ }^{\text {II }}$ Since 


\section{KoenraAd Brosens}

the cartoons of The Triumph of the Gods I and Telemachus I were the property of Albert and Philippe Auwercx, the editions listed in the Memoire de Vos were presumably also woven in the Auwercx workshop, and conceivably commissioned by Judocus or Jan-Frans de Vos. The set of The Four Continents and Related Allegories and the three Teniers sets may well have been produced in the de Vos workshop. The only set that was definitely woven in the De Vos workshop was the Art of War II. Apart from the fact that all known signed tapestries in this series bear the name 'De Vos' (and never any of the other Brussels tapissiers), De Vos added in his Memoire that 'one can pick whatever tapestries one wants' from the edition that was recorded, and that he could produce customised sets at various prices. These remarks are striking in as much as De Vos did not repeat them anywhere else in his Memoire. The obvious explanation would be that De Vos had immediate access to the cartoons of the Art of War II series and was therefore able to promote customised editions, while he had no such access to or control over the cartoons of the other sets mentioned in the Memoire and for that reason did not want to break them up. Given that the Art of War II cartoons were not mentioned as being the property of Judocus de Vos, neither in 1726 nor in I734, they must have been the property of his brother Jan-Frans.

Jan-Frans de Vos kept the workshop open after the death of Judocus de Vos. In I736, two years after the death of his brother, the City Council granted him additional privileges. ${ }^{113}$ According to the application that he filed, his workshop had eight looms. Interestingly, his tapestries were stored 'at the house of his cousin De Vos, registrar'. The 'registrar' can be identified as Judocus's son Jan-Frans de Vos (d. I759), registrar of the Raad van Brabant, ${ }^{\mathrm{II} 4}$ who had inherited the family home in the Nieuwstraat. ${ }^{\mathrm{II} 5}$ In other words, after the death of Judocus de Vos, but most probably also while he was still alive, De Vos's 'large house' was used as a grand backdrop for displaying tapestries and to impress potential buyers.

\section{Concluding Remarks}

Based on new archival findings, this essay maps the life and business strategies of Albert Auwercx and Judocus de Vos. New data show that categorising Auwerxc as a minor tapissier - a label he was assigned on the basis of the number of looms that he had, and the fact that he often collaborated with other tapissiers - ignores the underlying structure and dynamics of the industry. Brussels tapissiers created an intricate web of social networks that generated trust. It was this trust that paved the way for semistructured and flexible cooperation between small firms, which in turn allowed tapissiers to shoulder the ongoing investments and risks inherent in the industry. At the same time it offered them the room they needed to develop their economic potential. Judocus de Vos also belonged to the Brussels social and production networks, but made his name first and foremost as a commercial link and broker between Brussels, the AntwerpOudenarde production and trading complex and the European élite - particularly after I7I9 when he handed over the reins and assets of the De Vos workshop to his brother Jan-Frans.

Now that the image we have of the Brussels tapestry industry in the first half of the eighteenth century is more refined, it is clear that interpreting signatures on tapestries, and the dating of tapestries on the basis of these signatures, is a risky business. Albert 


\section{Revisiting Brussels Tapestry, I700-I740}

Auwerxc and Judocus de Vos collaborated with several tapissiers; worked as subcontractors; farmed commissions out; commissioned sets from other Brussels tapissiers; and bought sets on the market. The tapissier who signed could have owned the cartoons, and/or supervised the production of the set in his workshop, and/or financed the production, and/or bought the set - there is no universal rule.

\section{REFERENCES}

${ }^{\mathrm{I}} \mathrm{F}$. Huygens, 'Mozes in de Zuidnederlandse tapissierskunst. Traditie en vernieuwing in twee tapijten van Jasper van der Borcht', Bulletin des Musées Royaux d'Art et d'Histoire, LXv (I994), pp. 257-304; N. de Reyniès, 'Jean van Orley cartonnier. La tenture d'Achille au Musée JacquemartAndré', Gazette des Beaux-Arts, Cxxv (1995), pp. I55-76; N. de Reyniès, 'Jean van Orley. Une tenture de l'histoire de Psyché', Gazette des Beaux-Arts, Cxxv (I995), pp. 209-20; K. Brosens and G. Delmarcel, 'Les aventures de Don Quichotte. Tapisseries bruxelloises de l'atelier LeyniersReydams', Revue Belge d'Archéologie et d'Histoire de l'Art, LXviI (I998), pp. 55-92; K. Brosens, 'The Story of Psyche in Brussels tapestry c.r7oo. New data on Jan van Orley, Jan-Baptist Vermillion and Victor Janssens', The Burlington Magazine, CXLVII (2005), pp. 40I-06.

${ }^{2} \mathrm{~K}$. Brosens, 'Eighteenth century Brussels tapestry and the Goût Moderne. Philippe de Hondt's sets contextualized', Studies in the Decorative Arts, XIV (2006-2007), pp. 53-79.

${ }^{3}$ G. Delmarcel and F. Huygens, 'A propos du tapissier Jean-Baptiste Vermillion, du cartonnier Maximilien De Hase et d'autres ateliers bruxellois du XVIIIe siècle', CIETA-Bulletin, LXxiv (I997), pp. I46-58; and Brosens, 'Story of Psyche', pp. 40I-06.

${ }^{4} \mathrm{~K}$. Brosens, A Contextual Study of Brussels Tapestry, I670-I770: The Dye Works and Tapestry Workshop of Urbanus Leyniers (I674-I747) (Brussels: Koninklijke Vlaamse Academie van België voor Wetenschappen en Kunsten, 2004).

${ }^{5} \mathrm{~K}$. Brosens, 'Brussels Tapestry producer Judocus de Vos (I66I/I662-I734) - New data and design attributions', Studies in the Decorative Arts, Ix (2002), pp. 58-86; Brosens, A Contextual Study, pp. II - -I 8 and 3 III-I8.

${ }^{6}$ For the Brinck affair, see Brosens, A Contextual Study, pp. 37-4I.

7 A. Wauters, Les Tapisseries Bruxelloises. Essai Historique sur les Tapisseries de Haute et de Basse-lice de Bruxelles (Brussels: Baertsoen, I878), pp. 334, 339-40, 350 and 405.

${ }^{8}$ The late Margaret Swain (1909-2002), historian of embroidery, tapestry and furniture, discovered the documents in the archives of Hopetoun House, West Lothian, Scotland. She passed them on to Guy Delmarcel who entrusted them to the author a couple of years ago. For transcriptions and translations by the author, see Appendices I, 2 and 3: http://dx.doi.org/IO.II79/00404969I2Z.0000000000IO.SI; http://dx.doi.org/IO.II79/00404969I2Z.000000000Io.S2; http://dx.doi.org/I0.I I79/00404969I2Z.000000 o००IO.S 3 .

9 Wauters, Les Tapisseries, pp. 334, 339-40, 350 and 405.

${ }^{\text {ro }} \mathrm{H}$. Göbel, 'Die "Mythologischen Episoden” aus der Brüsseler Werkstatt des Albert Auwercx', Der Cicerone, XIX (I927), pp. 63I-38 focuses on the iconography of a mythological series and not on Auwercx. J. Denucé, Antwerpsche Tapijtkunst en Handel (Antwerp: De Sikkel, 1936), shows that Auwercx frequently worked as a subcontractor for the Antwerp tapestry dealer Nicolaas Naulaerts. G. Delmarcel, Flemish Tapestry (New York: Abrams, 1999) discussed Auwercx only briefly (especially p. 363). Brosens, A Contextual Study, pp. 302-05 offers more biographical information on the Auwercx family, yet it does not focus on the workshop.

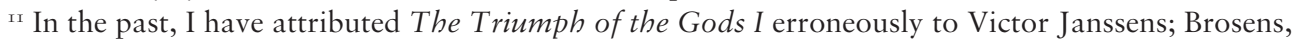
'Judocus de Vos', p. 7I; and Brosens, A Contextual Study, p. Ior.

${ }^{12}$ For this series, see G. Delmarcel, M. García Calvo and K. Brosens, 'Spanish family pride in Flemish wool and silk: The Moncada family and its Baroque tapestry collection', in T. P. Campbell and E. Cleland eds, Tapestry in the Baroque. New Aspects of Production and Patronage (New York: The Metropolitan Museum of Art/New Haven and London: Yale University Press, 20IO), pp. 284-3I5; 


\section{KoenraAd Brosens}

M. García Calvo, 'Correspondencia entre Fernando de Aragón (I644-I7I3), 8. Duque de Montalto, y su agente en Bruselas sobre la realización de la tapicería de la "Historia de la Casa de los Moncada", Archivo Español de Arte, LXXXiv (2011), pp. 283-94.

${ }^{13}$ The Story of Saint Paul can be attributed to Pieter Coecke van Aelst (I502-50); the Story of Moses can be attributed to a follower of Giulio Romano. See T. P. Campbell ed., Art and Magnificence: Tapestry in the Renaissance (New York: The Metropolitan Museum of Art/New Haven and London: Yale University Press, 2002), pp. 380-8I, 391-93 and 406-10.

${ }^{14}$ Particularly when one takes into account that a new coach cost fl.r,ooo at the time; Brosens, $A$ Contextual Study, p. 45.

${ }^{15}$ Brussels Stadsarchief (hereafter BSA), Parish Records (hereafter PR), 337, Io February I629.

${ }^{16}$ They married in I626; BSA, PR, 407, 26 April 1626.

${ }^{17}$ BSA, PR, 390, 8 May I654; BSA, PR, 4I4, 8 July I698.

${ }^{18} \mathrm{P}$. De Tienne, 'Contribution à une généalogie des tapissiers bruxellois de Pannemaecker', L'Intermédiaire des Généalogistes, LI (I996), p. 292. See also E. Duverger, 'Verdures uit het Brusselse atelier van Erasmus (III) en Frans de Pannemaker', Artes Textiles, XI (I986), pp. I07-I 5.

${ }^{19}$ For the De Pannemakers, see Campbell ed., Tapestry in the Renaissance.

${ }^{20}$ BSA, Treasury (hereafter T), I300, I8 February I67I.

${ }^{21}$ BSA, PR, 342, 20 February 1655; Brussels, Algemeen Rijksarchief (hereafter BARA), Notariaat General van Brabant (hereafter NGB), 2979, 25 April I740.

${ }_{22}^{2}$ BSA, PR, 343, I5 May I656; BSA, PR, 428, 3 October I669.

${ }^{23}$ BSA, PR, 334, I2 August I663; BSA, PR, 4I9, I2 February 1740. He died on Io February; Belgium, Private collection, Doodtboeck (hereafter DB), fol. 88.

${ }^{24}$ BSA, PR, 335, 25 November I664; BSA, PR, 4I9, 27 June I737. He died on 25 June; Belgium, Private collection, DB, fol. 74 .

${ }_{25}$ BSA, PR, 346, 26 March I666; BSA, PR, 428, 2I July I678.

${ }^{26}$ BSA, PR, 346, 2 September I667; BSA, PR, 4I6, 26 February 1723.

${ }^{27}$ BSA, PR, 347, I2 July I67I; BSA, PR, 42I, 2I September I752.

${ }^{28}$ BSA, PR, 348, 28 September 1672.

${ }^{29}$ BSA, PR, 349, 30 April I676; BSA, PR, 42I, I7 May I755.

${ }^{30} \mathrm{BSA}, \mathrm{PR}, 343$, I8 January I659; BSA, PR, 4I6, 2I December 1720.

${ }^{31}$ BSA, PR, 334, I7 October I660; BSA, PR, 4I8, I8 February 1733.

${ }^{32}$ BSA, PR, 4I 5 , 3I August 1709.

${ }_{33} \mathrm{BSA}, \mathrm{PR}, 334$, I7 October I660.

${ }^{34}$ BSA, PR, 334, I2 August I663; BSA, PR, 347, I2 January I670.

${ }_{35}$ BSA, PR, 335, 25 November 1664.

${ }^{36} \mathrm{~K}$. Brosens, 'The Story of Theodosius the Younger: a rediscovered tapestry set by Jacob Jordaens and his studio', The Burlington Magazine, CXLIX (2007), p. 380.

${ }^{37} \mathrm{BSA}, \mathrm{PR}, 346,2$ September 1667.

${ }^{38} \mathrm{BSA}, \mathrm{PR}, 347$, I2 July I67I.

${ }^{39} \mathrm{BSA}, \mathrm{PR}$, 349, 30 April 1676. For the Leyniers dye works, see Brosens, A Contextual Study, pp. 34-37.

${ }^{40}$ BARA, NGB, I964, 24 October and I4 November I667. The document pertaining to the establishment of the sick pay was published by E. Duverger, 'Een Troje-tapijt uit het Brussels atelier van Jan van Rottom van omstreeks I660', Artes Textiles, XI (I986), pp. I43-46.

${ }^{41}$ BARA, NGB, I962, I2 April I679; BARA, NGB, I966, 23 October i68I; BARA, NGB, I968, I6 December I687; A. Wauters, Liste Chonologique des Doyens des Corps de Métiers de Bruxelles de 1696 à 1795 dressée d'après des Documents Inédits. Ville de Bruxelles (Brussels: Baertsoen, I888), p. I3.

${ }^{42}$ Duverger, 'Een Troje-tapijt', pp. I46-47. See also W. G. Thomson, 'The "Diana Hunting" tapestries, belonging to Mr. Kennedy Jones', The Connoisseur, xxxv (I9I3), pp. 229-34. 


\section{Revisiting Brussels Tapestry, I700-I740}

${ }^{43} \mathrm{~K}$. Brosens, European Tapestries in the Art Institute of Chicago (Chicago: The Art Institute of Chicago/New Haven and London: Yale University Press, 2008), pp. I66-73.

${ }^{44}$ BARA, NGB, 7II, 26 April I678.

${ }^{45}$ BARA, NGB, 22, I9 January; and 25 June I688; BARA, NGB, 22, II September I69I.

${ }^{46}$ Brosens, A Contextual Study, pp. 65-75; K. Brosens, 'New light on the Raes workshop in Brussels and Rubens's Achilles Series', in Campbell and Cleland eds, Tapestry in the Baroque, pp. 20-33.

${ }^{47}$ In his 1944 The Great Transformation, Karl Polanyi (I886-I964) introduced the notion of 'embeddedness' to argue that in pre-capitalist times the economy was an organic part of society as it was embedded in social, religious and political institutions. Therefore, Polanyi claimed, phenomena such as trade and money were inspired by other motives than mere profit making. Mark Granovetter in his seminal 1985 essay Economic Action and Social Structure: The Problem of Embeddedness, which launched the 'New Economic Sociology', argued convincingly that in capitalist societies, too, economic action is embedded in social networks. For an introduction to Granovetter and economic sociology, see B. Convert and J. Heilbron, 'Where did the new economic sociology come from?', Theory and Society, xxxvi (2007), pp. 3I-54.

${ }^{4}$ As is convincingly shown in Granovetter's analysis of business groups (M. Granovetter, 'Coase revisited: business groups in the modern economy', Industrial and Corporate Change, IV (I995), pp. 93-I3I), Perrow's study of 'small firm networks' (C. Perrow, 'Small firm networks', in R. Swedberg ed., Explorations in Economic Sociology (New York: Russel Sage Foundation, 1993), pp. 277-402), Uzzi's examination of subcontracting relationships in the New York garment industry (B. Uzzi, 'The sources and consequences of embeddedness for the economic performance of organizations: the network effect', American Sociological Review, LXI (1996), pp. 674-98; B. Uzzi, 'Networks and the paradox of embeddedness', Administrative Science Quarterly, XLII (I997), pp. 35-67) and Dulsrud and Grønhaug's analysis of the Norwegian and Danish fish import-export business (A. Dulsrud and K. Grønhaug, 'Is friendship consistent with competitive market exchange? A microsociological analysis of the fish export-import business', Acta Sociologica, xx (2007), pp. 7-19).

${ }^{49}$ Brosens, A Contextual Study, pp. 59-60.

${ }^{5}$ When the Manufacture Royale des Gobelins was established in Paris in the early I66os, there was no carefully nurtured trusting ethic between the various parties; as a consequence, all weavers had to work on the premises so that Charles Le Brun, artistic director, 'puisse voir leurs ouvrages à tous momens, qu'il les puisse corriger, et qu'il voye qu'ils avancent, et s'ils ne perdent point leur temps'; cited in F. Joubert, A. Lefébure and P.-F. Bertrand, Histoire de la Tapisserie en Europe (Paris: Flammarion, 1995), pp. 167-68.

${ }^{51}$ Brosens, A Contextual Study, pp. 260-6I.

${ }_{52}$ Two six-piece editions of Telemachus I, one four-piece and one seven-piece edition of The Triumph of the Gods I, one six-piece edition of The Story of Rinaldo and Armida and, finally, four tapestries depicting The Story of Don Quixote, woven after cartoons that were presumably in the shared ownership of Jasper van der Borcht and Peter van den Hecke, or after cartoons owned by Jean-Baptiste Vermillion.

53 Brosens, A Contextual Study, pp. 273-78.

${ }^{54}$ Ibid., p. 369.

55 Ibid., p. 369.

${ }^{56}$ Ibid., p. 3 I2.

${ }^{57} \mathrm{BSA}, \mathrm{PR}, 4 \mathrm{I} 5$, I7 June I7II.

${ }^{58} \mathrm{BSA}, \mathrm{PR}, 337$, I2 November I630. His father was Johannes; his mother was Catharina du Caisson.

59 BSA, PR, 337, I9 March I629.

${ }^{60}$ BSA, PR, 4I 4, 26 January I704.

${ }^{6 r}$ BSA, PR, 344, 8 January I66r.

${ }^{62}$ BSA, PR, 345, 5 October I664; and BSA, PR, 420, 2 April I750. 


\section{KoenraAd Brosens}

${ }_{63}$ BSA, PR, 346, I2 August I666.

${ }^{64} \mathrm{BSA}, \mathrm{PR}, 349,29$ April 1676.

${ }^{65}$ BSA, PR, 4I6, 3 May I723.

${ }^{66}$ BARA, NGB, II46, I7 January I697.

${ }^{67} \mathrm{BSA}, \mathrm{PR}, 4 \mathrm{I} 8$, I 5 December I73I.

${ }^{68}$ BSA, RT, I300, fols 452r-53r, 3 September I674; BSA, RT, I304, fols 293v-94r, I8 June I687. One Hendrik de Vos died in I70I (BSA, 3408/74), but it is still not clear whether he was the son of the sculptor Marcus de Vos, or the son of Judocus de Vos and Magdalena Rombouts (BSA, PR, 344, 2 June I662), or the son of Judocus de Vos and Barbara Jacobs (BARA, NGB, 276, 7 November I687).

${ }^{69} \mathrm{BSA}, \mathrm{PR}, 46, \mathrm{pp} .204$ and 638.

${ }^{70}$ BARA, NGB, 4244, 8 March I732.

${ }^{71}$ BARA, NGB, 3419, I6 March I734; I7 March I734.

${ }^{72}$ Brosens, A Contextual Study, p. 3 I6.

${ }^{73}$ BSA, PR, 259, 5 November 1697. Godfather was Judocus's brother Jan Frans; godmother was Catharina Theresia Jacobs.

${ }^{74}$ According to the Doodtboeck Jacob de Vos was born in around I687; Brosens, A Contextual Study, p. 3I2.

${ }_{75}$ Brosens, A Contextual Study, p. 3 I2.

${ }^{76}$ Ibid., p. 3I2. De Oudenaardse Van Verren family deserves critical modern research; important data was published by E. Duverger, Jan, Jacques en Frans de Moor, Tapijtwevers en Tapijthandelaars te Oudenaarde, Antwerpen en Gent (I560 tot ca. I680) (Ghent: Interuniversitair centrum voor de geschiedenis van de Vlaamse tapijtkunst, I960); and in the useful yet hardly academic F. Van Ommeslaeghe, De Oudenaardse Wandtapijten en hun Wevers in hun Historisch Kader (Oudenaarde: Davidsfonds, I996), pp. 235-68. For tapestry production in Oudenaarde, see I. De Meûter and M. Vanwelden eds, Oudenaardse Wandtapijten van de $16^{\text {de }}$ tot de $18^{\text {de }}$ Eeuw (Tielt: Lannoo, I999), and the mine of information by M. Vanwelden, Productie van Wandtapijten in de Regio Oudenaarde. Een Symbiose tussen Stad en Platteland ( $15^{\text {de }}$ tot $I 7^{\text {de }}$ eeuw) (Leuven: University Press, 2006).

${ }^{77}$ For examples of similar networks, see inter alia M. Vanwelden, 'Groei, bloei en teloorgang van de wandtapijtnijverheid in Oudenaarde', in De Meûter and Vanwelden eds, Oudenaardse Wandtapijten, pp. 93-95; and Brosens, 'The Raes workshop', pp. 20-28.

${ }^{78}$ Brosens, A Contextual Study, p. $3 \mathrm{I} 2$.

79 Ibid., p. 3I2.

${ }^{80}$ The series, now lost, was finished before the summer of I700; ibid., p. 3 I 3 .

${ }^{81}$ G. Delmarcel, 'Nieuwe gegevens over de wandtapijten van het Nieuwe Testament door Judocus de Vos te Malta (I699-I700)', Revue Belge d'Archéologie et d' Histoire de l'Art, LIV (1985), pp. 29-44; G. Delmarcel, 'De Rubenstapijten te Malta/Rubens's tapestries in Malta', in Rubenstextiel / Rubens's Textiles (Antwerp: Stad Antwerpen, I997), pp. I36-5I.

${ }^{82}$ BARA, NGB, I233, 8 August I699 (Ovid's Metamorphoses); BARA, NGB, 3650, 29 July I700 (Il Pastor Fido).

${ }^{83}$ Brosens, A Contextual Study, pp. 312-I3.

${ }^{84}$ Antwerp, Felixarchief (hereafter AF), Notarissen (hereafter N), 858, 3I July I702.

${ }^{85}$ The Memoriael was published by Denucé, Antwerpsche Tapijtkunst, pp. II6-372.

${ }^{86}$ Brosens, European Tapestries, pp. I9I-98.

${ }^{87}$ Delmarcel, 'De Rubenstapijten', pp. I42-43.

${ }^{88}$ Brosens, A Contextual Study, p. II9. For the series, see J. T. de Raadt, 'Eene bestelling van brusselsch tapijtwerk in het jaar I70I', in J. T. de Raadt, Mengelingen over Heraldiek en Kunst (Antwerp:

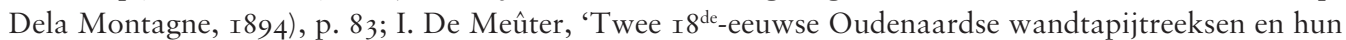
bronnen. Don Quichotte en Il Pastor Fido', Handelingen van de Geschied-en Oudheidkundige Kring van Oudenaarde, xxxv (1998), pp. 238-47. 


\section{Revisiting Brussels Tapestry, I700-I740}

${ }^{89}$ An initial exploration brought two separate pieces to light that presumably belong to the series: a Theater Scene that was in the collection of the New York firm French \& Co. in the early twentieth century (GCPA 0239225), and a similar Theater Scene in the Palazzo Caetani, Rome, an image of which is included in B. Phillips, Tapestry (London: Phaidon, I994), p. I06.

${ }^{90}$ Lang was also Nicolaas Naulaerts' agent, as emerged from Memoriael Naulaerts; Denucé, Antwerpsche tapijtkunst, pp. I24, I49, I54-55, I6I, I68, I76, I87, I9I-92, 249, 275-77 and 28I.

${ }^{91}$ Brosens, 'Judocus de Vos', pp. 62-63. Naulaerts's cartoons of The Four Continents were listed in the 1702 contract; Jan van Verren's Perseus cartoons were listed in his probate inventory; AF, Nio56, I6 May I7II.

${ }_{92}$ BARA, NGB, 23, 7 June I702; published by Brosens, A Contextual Study, p. 206.

${ }_{93}$ Ibid., p. 292.

${ }^{94} \mathrm{AF}, \mathrm{N}, 858,6$ October 1704 .

${ }_{95}$ Brosens, A Contextual Study, pp. 3I4-I 5.

${ }^{96}$ Wauters, Les Tapisseries, p. 35 I.

${ }_{97}$ Brosens, A Contextual Study, p. 3I5.

${ }^{98}$ Ibid., p. 316.

99 Ibid., p. 316.

${ }^{100}$ BARA, NGB, 4238, 8 July I726.

ror This document (BARA, NGB, 34I9, I6 March I734) has been mentioned in the literature (Brosens, 'Judocus de Vos', p. 82 and Brosens, A Contextual Study, p. 3I8), but its disturbing message, that is, the finding that De Vos had no sets of cartoons, was left unsaid.

${ }^{102}$ In January I72I, Hope contracted William Adam (I689-I748) to redesign parts of Hopetoun House which had been built between 1699 and I702. For Hope and Hopetoun House, see T. F. Henderson, 'Hope, Charles, first earl of Hopetoun (I68I-I742)', in Oxford Dictionary of National Biography. Available from http://www.oxforddnd.com/view/article/I37I6 [Accessed: I November 20II]; A. Rowan, 'The building of Hopetoun', Architectural History, XxVII (I984), pp. I83-209; J. Gifford, William Adam, I689-I748: A Life and Times of Scotland's Universal Architect (Edinburgh: Mainstream, 1989); James Macaulay, 'Sir William Bruce's Hopetoun House', Architectural Heritage, XX (2009), pp. I-I4.

${ }^{\text {ro3 }}$ Hope also contracted Urbanus Leyniers; see the Memoire written by Leyniers, which will be studied in a separate contribution.

${ }^{104}$ The handwriting of the Memoire is identical to that of a letter written by De Vos in I7I5; a photo of the letter was published by J. Bapasola, Threads of History. The Tapestries at Blenheim Palace (Lydney: Lightmoor Press, 2005), p. 80. The document has an inscription on the back that reads 'De Voss Brussels Tapistrie May $8^{\text {th }} 1727$ '. It is in a different hand, possibly that of Hope's contact in Brussels or that of Hope's secretary.

${ }^{\text {ros }}$ For the set, see N. de Reyniès, 'Charles Poerson et la tapisserie', in B. Brejon de Lavergnée, N. de Reyniès and P.-N. Sainte-Fare-Garnot eds, Charles Poerson I609-I667 (Paris: Arthena, I997), pp. I7I-83; K. Brosens, 'Bruxelles/Paris/Bruxelles. Charles de La Fontaine et la diffusion des modèles des tapisseries de Charles Poerson à Bruxelles', Revue Belge d'Archéologie et d'Histoire de l'Art, LXXVI (2007), pp. 43-60; Brosens, European Tapestries, pp. I74-78.

${ }^{106}$ For Teniers' Months, see Brosens, ibid., pp. I83-86. For his Continents series, see J. H. Hyde, 'L'iconographie des quatre parties du monde dans les tapisseries', Gazette des Beaux-Arts, LXVI (I924), p. 262.

${ }^{107}$ For a discussion of Van Schoor's The Four Continents and Related Allegories, see Brosens, European Tapestries, pp. I87-90. For illustrations of Continents tapestries, see E. J. Kalf, 'Vier deelen van de wereldt als andersints', Artes Textiles, x (198I), pp. 235-47.

${ }^{\text {ro8 }}$ While it was already known that the Triumph of the Gods series included depictions of Apollo, Bacchus, Diana, Flora, Neptune, and Vulcan (the six titles recorded by De Vos) (see Brosens, 'Judocus de Vos', p. 66; Brosens, A Contextual Study, pp. 152-55), the survey of the pieces that made part of 


\section{KoenraAd Brosens}

The Story of Telemachus I reveals that the series included two scenes that were not mentioned in previous analyses of the set, i.e., The Battle of Telemachus and The Hunt of Telemachus (Brosens, 'Judocus de Vos', p. 70; and Brosens, A Contextual Study, pp. I66-68). The tapestry of The Battle of Telemachus shown in Brosens, A Contextual Study, p. 486 does not belong to the Story of Telemachus II produced by Leyniers, but to the Story of Telemachus I. There are, as yet, no known tapestries that can be identified as The Hunt of Telemachus from the Story of Telemachus I series.

${ }^{109}$ Brosens, ibid., pp. I4I-44.

${ }^{\text {Iro }}$ For the series, see K. Brosens, 'A naval battle', in T. P. Campbell ed., Threads of Splendor: Tapestry in the Baroque (New York: The Metropolitan Museum of Art/New Haven and London: Yale University Press, 2007), pp. 477-83; Brosens, 'Philippe de Hondt', pp. 57-58; and A. Wace, The Marlborough Tapestries (London: Phaidon, I968), pp. 90-97.

${ }^{\text {III }}$ For the Peemans sale, see K. Brosens, “Wie durft daerop bieden?” Tapestry cartoons, preparatory sketches and tapestries at auction, I650-I750', in D. Lyna, F. Vermeylen and H. Vlieghe eds, Art Auctions and Dealers. The Dissemination of Netherlandish Art during the Ancien Régime (Turnhout: Brepols, 2009), pp. 90-92.

${ }^{I I 2}$ As usual, De Vos recorded the dimensions of the pieces and the price per ell, but, unusually, he failed to give titles or descriptions of the tapestries. The omission can easily be explained. Identification of the Plutarch scenes is a knotty problem, even to tapestry scholars who have access to all possible sources, and De Vos was not at all familiar with the iconography of the series as it had been commissioned by Urbanus Leyniers. For the set, see I. Denis, 'Tenture des Hommes Illustres de Plutarque d'après des modèles de Victor-Honoré Janssens', in Les Choix de la Mémoire. Patrimoine Retrouvé des Yvelines (Paris: Somogy, I997), pp. I3I-34; and Brosens, A Contextual Study, pp. I4I-44. It is not clear how and when this set became the property of the De Vos firm. The Mémoire de Goís, which surveys the output of the Leyniers workshop between I7I3 and I734, lists two editions of the set that were produced prior to I727. One was bought by Daniël Wolff von Dopff in I7I3, the other by Lothar Joseph Dominic of Königsegg and Rothenfels in I7I5; Brosens, A Contextual Study, pp. 25I [I] and 252 [5]. There is a possibility that the edition recorded in the Memoire de Vos is Daniel Wolff von Dopff's edition which then entered the market after his death in I7I8. It is also possible, of course, that the Mémoire de Goís does not include all sets sold by Leyniers.

${ }^{113}$ BSA, PR, 778, I6 October I636. This document was mentioned in Brosens, 'Judocus de Vos', p. 62, yet curiously not included in Brosens, A Contextual Study, p. 318.

${ }^{114} \mathrm{~J}$ an Frans II de Vos's profession is recorded in a handful of documents; for example, BARA, NGB, 34I9, I6 March I734; BARA, NGB, II73, I4 August 1735.

${ }^{\text {II }}$ BARA, NGB, 34I9, I6 March I734.

Koenraad Brosens is Professor in the History of Art Department, University of Leuven. His research focuses on early modern Flemish and French tapestry and the entrepreneurial and networking strategies developed by tapestry producers. His publications include A Contextual study of Brussels Tapestry, I670-I770 (Brussels, 2004), European Tapestries in The Art Institute of Chicago (Chicago, New Haven and London, 2008) and Rubens: The Constantine Series (CRLB) (London, 20II). Koenraad Brosens was acclaimed Laureate of the Royal Academy of Belgium in 2010. 